This is an author's final draft. The article has been published by Ethnopolitics. (2015) 14:1, pp.72-93:

http://www.tandfonline.com/doi/full/10.1080/17449057.2014.933051\#.U8EwofldWSo

\title{
Identity and Integration of Russian Speakers in the Baltic States: A Framework for Analysis
}

Dr Ammon Cheskin, Central and East European Studies, University of Glasgow

$\underline{\text { Ammon.cheskin@glasgow.ac.uk }}$

\begin{abstract}
Following a review of current scholarship on identity and integration patterns of Russian speakers in the Baltic states, this article proposes an analytical framework to help understand current trends. Rogers Brubaker's widely-employed triadic nexus is expanded to demonstrate why a form of Russian-speaking identity has been emerging, but has failed to become fully consolidated, and why significant integration has occurred structurally but not identificationally. By enumerating the subfields of political, economic, and cultural 'stances' and 'representations' the model helps to understand the complicated integration processes of minority groups that possess complex relationships with 'external homelands', 'nationalizing states' and 'international organizations'. Ultimately, it is argued that socio-economic factors largely reduce the capacity for a consolidated identity; political factors have a moderate tendency to reduce this capacity; while cultural factors generally increase the potential for a consolidated group identity.
\end{abstract}

This article proceeds by reviewing the scholarly literature from 1992-2014 relating to Russians/Russian speakers in the Baltic states. The review is based on an analysis of various literatures that have focused directly on Russian speakers in the one of more of the Baltic states. The main questions addressed in this article are: to what extent has a 'Russianspeaking nationality' emerged in the Baltic states?; what are the main factors that impede or facilitate the materialization of such an identity?; and how can we understand contemporary integration trends among Russian speakers? The articles reviewed include studies of identity, integration, socio-economics, education policy, language practice, and ethnic relations generally. 
The review is used in order to construct a coherent theoretical and analytical framework to understand current trends in the development of Russian-speaking identities in the Baltic states. Rogers Brubaker's 'triadic nexus' is used as a starting point for this task. By elaborating upon Brubaker's nexus, a more causal model is developed that can help policymakers and academics understand more fully contemporary identificational trends among Russian speakers in the Baltic states.

The analysis of previous research is used to demonstrate the validity of distinguishing between cultural, political, and economic forms of attraction and repulsion. In so doing this paper argues that it is possible to conceptualize more fully the complex, 'quadratic' interactions between Russian speakers, the Baltic states, the European Union, and Russia. As the analysis shows, Russia generally has the potential for high cultural attraction but relatively low political and economic attraction for Russian speakers, while the Baltic states have low cultural attraction, relatively high economic attraction, and contradictory levels of political attraction. These factors mean that there are conflicting pressures on Russian speakers to consolidate their internal identity and to integrate into the social and political lives of the Baltic states. This expanded nexus also has direct relevance to the study of other minority groups that have potentially important relationships with 'external homelands' and 'nationalizing states'.

\section{Russian-speaking nationality?}

One of the most pressing questions that has concerned researchers of post-Soviet, Russianspeaking identity in the Baltic states relates to the question of group identity. To what extent is it valid to recognize a well-defined community of Russian speakers? ${ }^{1}$ Should Russian speakers be treated as a national or ethnic minority or does the large diversity within this group make such categorizations problematic?

In the immediate aftermath of the collapse of the Soviet Union scholars were unclear how to label the non-Estonian/Latvian/Lithuania populations of the Baltic states. The appropriateness of treating Russians or Russian-speakers as a singular group has been questioned, as any given label comes with its own misleading assumptions (Poppe \& Hagendoorn 2001). This was evidenced by early studies that found it problematic to talk of a 
unified Russian/Russian-speaking community with common interests (Kirch 1992; Kirch, Kirch \& Tuisk 1993; Aasland 1994; Melvin 1995).

Numerous factors have been identified to explain the weakness of collective identity in this early, post-Soviet period. Graham Smith $(1996,208)$ notes that Russian speakers were divided by their rootedness (length of residence in the Baltic region), language practice, occupation, and nationality (national'nost'). Particular attention has been paid to the legacy of Soviet nationality policies as an explanatory factor for weak collective identities (Agarin 2010; Brubaker 1994). Multilayered Soviet practices resulted in the absence of a strong sense of Russianness when the Soviet Union collapsed. For example, Russian and Soviet were terms that were often conflated. Many Russian speakers in the Baltic states initially considered themselves first and foremost Soviet citizens rather than Russians (Vihalemm \& Masso 2003, 101). In 1990, for example, Linz and Stepan $(1996,411)$ found that only $4.2 \%$ of non-Latvians in Latvia stated that they felt primarily 'of Russia'. In Estonia the corresponding figure was $12 \%$. Indeed, the Soviet practice of rigidly demarcating and maintaining personal definitions of nationality (natsional'nost') meant that many Russian speakers actually considered themselves to be Ukrainian, Belarusian etc. rather than Russian.

The fragmented nature of these identities leads us to question the validity of studying Russian speakers as a meaningful group. However, in the post-Soviet era, a number of scholars have also pointed to the relative consolidation of Russian-speaking identity (distinct from Russian identity). David Laitin (1995) has gone furthest in identifying an emergent 'Russian-speaking nationality' in the Baltic states. This identity is distinct from Russian identity and is consolidated around the 'Balticization' of Russian speakers (Melvin 1995). Supporting this view there is much evidence that Russian speakers in the Baltic states view themselves as fundamentally different from Russians in Russia (Zepa 2006; Vihalemm \& Masso 2003; Cheskin 2013; Fein 2005).

Additionally, there is evidence that a form of group consciousness has been evolving which centres around the linguistic categorization of 'Russian-speakers' (Tabuns 2010, 260-264; Cheskin 2010; Kronenfeld 2005, 272; Cheskin 2013, 293-294). This is clearly apparent in the media where the term Russian-speaker is increasingly used as a linguistic signifier to describe an otherwise fairly disparate group (Cheskin 2010; Khanov 2002, 14). It is in Latvia 
where this trend is most apparent, especially following the country's 2003/4 education reforms that demanded Russian schools (schools whose language of instruction was Russian) move to conducting at least $60 \%$ of their instruction in Latvian. This led to mass protests as individuals increasingly defined themselves by their use of the Russian language (HoganBrun 2006; Cheskin 2010).

The literature therefore identifies two seemingly contradictory tendencies - on the one hand the disavowal of certain links with Russia, and fragmentated identities, and on the other hand a relative consolidation of linguistic identity, centring on the Russian language. While, on first inspection, this may appear to present somewhat of a conundrum, in fact it is potentially explained when we distinguish between cultural and political forms of identification. Russian-speaking identity in the Baltic states shows some signs of consolidating around cultural preferences, notably the Russian language. At the same time, political and territorial links with Russia seem to be weakening. These ideational developments have great significance not only for Russian-speaking identities but also for the integration strategies pursued by Russian speakers. For one thing this trend towards identification along linguistic lines (Cheskin 2012, 326-327; Cianetti 2014, 2) has meant that, in the Baltic states, Belarusians, Ukrainians, and other Soviet nationalities are potentially able to find a discursive place within a well-defined imagined community. ${ }^{2}$ Culturally at least, this opens up the possibility for Russia to exert a meaningful influence, not just over Russians, but also over a broader categorization of Russian speakers.

\section{Russian speakers and integration}

Many observers have examined the issue of Russian-speaking identities from the perspective of the integration dynamics inherent within the Baltic states. Such research has largely been informed by John Berry's theoretical model of inter-cultural relations (Berry, 1997). Based on a cross-cultural psychology approach, Berry notes the importance of cultural interactions in determining human behaviour (6). He outlines four main acculturation models for individuals who are faced with cross-cultural contact: assimilation (giving up one culture and adopting another), integration (embracing both cultures), separation (maintaining one culture and avoiding contact with another), and marginalization (alienation from both cultures). 
The theme of integration has been most visible in Latvia and Estonia, where, citizenship was initially withheld from the majority of Russian speakers. This was grounded on the principle that the Baltic states had been illegally occupied by the Soviet Union. Soviet-era immigrants, therefore, did not constitute a legal part of the countries' 'core nations' (Smith et al. 1998). Following international pressure, citizenship laws were finally introduced allowing Russian speakers to naturalize if they could meet certain requirements, including language knowledge and having a basic grasp of the country's history (see Barrington 2000).

Eduard Ponarin $(2000,1538)$ has noted that because of increasing numbers of Russian speakers who have thus been able to acquire citizenship, there is now a 'race between intergenerational assimilation and increasing political power of the Russophone population.' On the one hand there is pressure on non-titular ${ }^{3}$ groups to integrate, or assimilate, into Baltic societies, therefore diluting the strength of any Russian-speaking identity. On the other hand the increased political power that accompanies an increase in the size of a potentially ethnicized electorate could lead to the opposite effect and an increase in the political capital of a consolidated Russophone identity.

An assessment of which of these competitors, 'integration/assimilation' or 'political consolidation', is currently leading the race is complicated. In 1998 David Laitin proposed a competitive assimilation argument, positing that Russian speakers would assimilate into Baltic societies both linguistically and culturally. He based this assessment on his 'tipping' model of identity formation. As soon as Russian-speaking individuals perceived the rational benefits (both economically and socially) of learning the state language as greater than maintaining monolingualism, they would learn the state language and assimilate (21-24).

Notwithstanding the theoretical sophistication of Laitin's reasoning, subsequent studies have shown that a majority of Russian speakers in Estonia, Latvia, and Lithuania have a preference for integration over assimilation (Kemppainen et al. 2004; Kronenfeld 2005; Pisarenko 2006; Šūpule 2007; Kasatkina 2006). These studies show clear evidence that Russian speakers commonly have a desire to learn the culture and language associated with their state of residence, whilst simultaneously maintaining Russian cultural and linguistic identities. While it is apparent that Russian speakers are increasingly likely to learn Estonian, Latvian and Lithuanian (Zabrodskaja 2009; Ernstsone \& Mežs 2008, 195) they are no less 
likely to want to display their cultural 'Russianness'. This leads Pisarenko $(2006,767)$ to the conclusion that it is more appropriate to talk about 'competitive integration and bilingualism than assimilation'.

Significantly, the current body of research on Latvia and Estonia challenges linear assimilation models which predict that increased integration in one area (for example, linguistic proficiency of the majority language) will lead to increased integration overall, and eventually to full assimilation into the core society. Nimmerfeldt, Schulze and Taru's (2011) study of second generation Russians in Estonia points to the misplaced, linear assumptions that have underpinned government integration policy in both countries. The authors employ four conceptual dimensions of integration which are often used in the literature: structural, cultural, social, and identificational (Heckmann \& Schnapper 2003, 10), ${ }^{4}$ and analyse survey data accordingly.

At the heart of the Estonian and Latvian governments' early programmes was the conviction that the success of their integration strategies rested upon improving structural integration (i.e. increased access to the countries' political and social institutions) by raising Russian speakers' linguistic knowledge of the official state languages. However, as Nimmerfeldt et al. note, the riots in the centre of Tallinn in 2007 (see below) were carried out by youth who, in many instances, were highly proficient in Estonian. This has led policy makers in both countries to reassess their integration policies. By studying this phenomenon along these four axes, it is possible to see that, contrary to the expectations of policy-makers, Russian speakers with higher levels of structural integration do not generally display significant increases in social or identificational integration. The only positive and statistically significant relationship was between structural integration and cultural integration (measured by Estonian language knowledge).

This raises the question of why integration does not follow the linear model that has been identified in other geographical areas. Kruusvall, Vetik, and Berry $(2009,15)$ cite negative attitudes of the majority group, rather than demographics or socio-economic factors, as the central impediments for successful integration. Indeed, Kulliki Korts $(2010,117)$ observes that there is a big difference in the way that integration is perceived from an Estonian, compared with a Russian-speaking, perspective. Consequently, it is a weakness of the 
current literature that relatively little focus is placed upon the positions of majority Latvian and Estonian groups vis-à-vis Russian speakers.

Brigita Zepa et al $(2006,26)$, in one of the most comprehensive studies of integration practice in Latvia, and one of the few to focus on majority opinions, found that among Latvians there was actually broad support for non-Latvians who pursued either assimilation or integration strategies. In their survey of over 600 Latvian respondents, integration strategies were rated marginally more favourably than those of marginalization.

This seemingly contradicts the hypothesis that Estonian and Latvian attitudes impede the integration process. However, in addition to prevalent societal attitudes of the majority group it is important to consider the institutional realities that underpin the integration programmes. A number of authors, for example, highlight the discrepancy between the stated aims of Estonian and Latvian integration policies and their actual institutionalization (Pettai 2003; Agarin 2009; Malloy 2009). As Timofey Agarin argues, the institutions connected with the integration programmes have been 'designed to attend to the interests of the dominant ethnic group' (Agarin 2009, 199). In Agarin's analysis of Latvia's integration programme from 2001 to 2008, he notes that Latvians had a privileged role in the implementation of its activities, while little room was given to minorities to articulate demands. Tove Malloy is not as critical of the Estonian programme. She notes, however, that while multiculturalism has often been alluded to in official documents, it is a particularly Estonian-centric form of multiculturalism that privileges the core Estonian language and culture $(2009,235)$.

\section{Socio-economics and Russophone identity}

Another factor that is often cited for the failure of integration policy centres is socioeconomics. While Laitin's economically driven rational choice model of assimilation has been largely rejected, a number of commentators still see the prime importance of socioeconomic factors in separating the titular groups from Russian speakers. Magdalena Solska (2011), for example, views Estonia's 'Bronze Soldier' riots through the prism of socioeconomics more than identities. In 2007 predominantly Russian-speaking youth took to the streets of Tallinn in violent protest against the government's decision to relocate a controversial Soviet Second World War memorial. ${ }^{5}$ While it was noted that many 
participants waved Russian flags and shouted pro-Russian, anti-Estonian slogans, Solska argues that the protesters were motivated because they 'felt that Estonians had better opportunities for jobs and education as well as for participation in political and community life because of their belonging to the core nation' $(2011,1101)$.

Economic studies of average wage earnings suggest that, even controlling for geographical segregations, levels of education, and language skills, non-Latvians and non-Estonians face an 'ethnic wage gap' (Leping \& Toomet 2008). For Estonia the mean wage was found to be as much as $10-15 \%$ higher for Estonian workers than non-Estonians. In Latvia Mihaels Hazans' analysis of economic data from 2002 showed a 10\% wage gap between Latvians and other ethnic groups $(2005,39) .{ }^{6}$ This leads some authors to label Latvia and Estonia 'regimes of discrimination' (Hughes 2005a; Woolfson 2009). ${ }^{7}$ For James Hughes $(2005 a, 744)$ these regimes rely on three main policy pillars: denial of citizenship, cultural subordination, and restriction of political and economic participation. Citizenship and cultural subordination certainly merit intense scrutiny. However, as Charles Woolfson $(2009,960)$ suggests, economic data in the Baltic states should be treated cautiously as they do not account for the significant size of the informal economy. Accordingly, Aasland and Fløtten have suggested that 'ethnicity is not a decisive factor in explaining income inequalities in presentday Estonia and Latvia' (2001, 1047).

Even if this assessment is more accurate than that of Hughes, it is still important to consider the regime of discrimination argument. Objective economic realities are not always as important as prevailing economic perceptions. Therefore it is not sufficient solely to consider the impact of economic discrimination. Instead we should also be aware that political and cultural practices may lead to increased perceptions of economic discrimination. In the 1990s language legislation was introduced in the Baltic states demanding proficiency in the state languages (Estonian, Latvian, Lithuanian) in order to find employment in certain professions (Dobson \& Jones 1998 41-42). Arguably, however, this has had minimal effect on economic inequality. A majority of professions which require the highest levels of linguistic proficiency are in the poorly-paid public sector. The language laws therefore have greatest effect in excluding monolingual Russian speakers from poorly-paid public sector jobs (Toomet 2011, 529). Nevertheless, the fact that these restrictions exist (irrespective of real 
economic consequences) can understandably lead to perceptions that the state is inherently biased towards 'its' majority group.

For this reason Geoffrey Evans (1998) cites state policies and perceptions of discrimination as the two main factors leading to ethnic polarization in Estonia from 1993-1995. Evans employs the conceptual framework of exit, voice and loyalty as adapted from Hirshman's economic theory of consumer behaviour. ${ }^{8}$ Because Evans found evidence that perceptions of discrimination were high, and that Estonian society was ethnically polarized, he logically foresaw the 'eventual emergence of a mobilized ethnic political voice within Estonia' (57). Having the advantage of hindsight it appears this prediction was somewhat overstated. Instead all three Baltic states have been largely remarkable for their general lack of ethnic mobilization among Russian speakers. This might be expected in Lithuania where the proportion of Russian speakers is comparatively much lower. But it is also true for Latvia, ${ }^{9}$ and even more so for Estonia. In Estonia, ethnic Russian political parties have fared poorly in elections and, with the notable exception of the 'Bronze Nights' in 2007, violent mobilization has rarely occurred in any form. In this light it is worth revisiting socio-economic arguments from a different perspective.

From a purely Baltic perspective, economic discrimination, and perceptions of economic discrimination, may well have aided the consolidation of a form of Russian-speaking identity. However, if we take a more international perspective, and examine socio-economic factors in relation to Russia, then we can see why Russophones in the Baltic states have been so politically passive (adopting strategies of symbolic exit as well as loyalty rather than voice). When it was clear that violent patterns of ethnic conflict were not developing in the Baltic states, a number of commentators started to search for explanatory variables to explain this lack of violence. Ain Haas, writing in 1996, considered a number of important explanations including political culture, history, and relative power balance between the two main ethnic groups. Significantly one of the variables singled out by Haas was the relatively high pace of economic reform in Estonia compared to Russia. Baltic Russians, he noted, 'feel that they would have little to gain from Russia' $(1996,70)$ where the economic situation was more chaotic and had fewer job prospects. 
For Magdalena Solska (2011), these economic factors help to explain why Estonia's internal ethnic tensions are less strained than Latvia's. Solska presents an optimistic (I would strongly suggest overly optimistic) account of Estonia's success in creating a unified political community, where 'ethnicity is not politicised any more' (1106). Nevertheless, while Solska's optimism should be questioned, she presents a good case to suggest that Estonia has been more successful than either Lithuania or Latvia in this regard. At the heart of this success Solska cites the economic performance of the Estonian government which has led to increased trust in political institutions and therefore increased value in Estonian citizenship compared with either Lithuania or Latvia (1104). This corresponds with the argument put forward by Külliki Korts $(2009,130)$ and Vihalemm and Kalmus $(2009,110)$ that Estonian Russians have become more similar to Estonians in their general thought patterns, and somewhat differentiated from their parents as a result of Estonia's consumerist, and globalized culture.

Additionally, there is evidence that Russian-language media and political discourses in the Baltic states have been slowly shifting away from an exclusive focus on discrimination, to a more optimistic assessment of the economic position of Russian speakers. In Latvia, where Russian maintains a more pervasive influence than in the other two Baltic states, an increasingly popular observation is that tri-lingual (Russian, Latvian, and English) Russian speakers often have an inherent advantage in the labour market over their bi-lingual (Latvian and English) Latvian counterparts (Cheskin 2010, 342; Cheskin 2013, 307). Discourses of ethnic discrimination, while not disappearing, are therefore being interspersed with more optimistic accounts.

Overall we can conclude that the socio-economic picture for Russophones in the Baltic states is complex. While, on the one hand, perceptions of economic discrimination have arguably aided the formation of a consolidated form of identity, recent developments suggest that socio-economic factors may also have a positive impact on integration. However, these more positive trends have not been sufficient for experts to rate Latvia and Estonia's integration programmes as successful. A wide-ranging study in 2010, while noting some positive trends, concluded that Latvian society remained 'not very integrated' (Muižnieks 2010, 284). In Estonia, criticisms that the 2000-2007 integration programme neglected socio-economic concerns (Enrst and Young Baltic 2009, 7) led to a more comprehensive focus on non- 
linguistic aspects of integration for the 2008-2013 programme. While there are some positive signs from the preliminary monitoring report of the 2008-2013 programme (Estonian Ministry of Culture), the report nonetheless categorizes $50 \%$ of the county's nonEstonians as poorly or not integrated, while only $21 \%$ are considered integrated.

It therefore appears that structural integration (increased access to economic and political opportunities) has not led directly to greater social and identificational integration. Consequently we can see that language skills, access to citizenship, and socio-economic wellbeing are not the only factors that determine the levels of social and identificational integration. Another area of ever more importance to researchers and policy-makers is the phenomenon of collective memories.

\section{History, memory and state narratives}

For Vita Zelče $(2009,54)$ one of the most significant factors in the failure of Latvian integration policy remains 'collective memory and the inability to achieve a convergence of historical perceptions' between different ethnic groups. In the Baltic states a great deal of research into collective memories has been conducted, often focusing on societal divisions between Russian speakers and their Latvian/Estonian/Lithuanian counterparts, or on the tensions between the Baltic states and Russia (Onken 2007; Onken 2010; Cheskin 2012; Berg \& Ehin 2009; Hackmann \& Lehti 2008).

This interest was largely sparked by the 2007 'Bronze soldier' riots in Estonia's capital. As discussed above, for many this signified the failure of state integration policy, and the limitations of a linguistically-driven approach. Tellingly, in the Latvian government's Guidelines for National Identity, Civil society and Integration Politics, approved in 2011, one of the central foci of social integration is now 'the creation of collective social memory' (Latvian Ministry of Culture 2011, 6).

The literature commonly accepts that there is a significant difference in how Russian speakers view the region's $20^{\text {th }}$ century history when compared to the titular groups (Gruzina 2011; Wertsch 2008; Zelče 2009; Vihalemm \& Jacobson 2011). Following Russia's criticisms of Estonia's memory politics, this divide has led to what Mälksoo refers to as a 'memory war' (2009). The differences of historical interpretations and collective memories 
centre on competing narratives of Soviet history. Russian speakers are more likely to deny that the Soviet Union occupied the Baltic states, and are more likely to associate the Soviet Union with positive achievements such as the creation of industry, job security, and welfare provision (Wertsch 2008; Zelče 2009; Cheskin, 2013).

For many scholars this memory divide is a natural result of the state and nation-building policies pursued by all three Baltic states in the late Soviet and early independence periods. In the Baltic states grand narratives of the past were invoked which were clearly linked to the emergent independent states (Smith et al. 1998, 99-109; Eglitis 2002). While Lithuania was not as explicit in tying its citizenship to these historical narratives, it was nonetheless clear that Lithuanian language and culture were to be the bases for Lithuanian state and nationhood.

The prominence of memory in recent scholarship shows that Russia can have a potentially significant influence on Russian-speaking identity in the Baltic states. Russophones are exposed to the cultural and political memory narratives of the Russian state through extensive consumption of Russia's media (Lerhis 2007: 54), and many continue to feel close cultural connections to the identities signified by Russia's officially propagated collective memories (Cheskin 2013, 296).

In terms of integration, the issue of memory also demonstrates that certain forms of identity stand apart from linguistic, socio-economic, and structural factors. If we are to understand the integration and identity dynamics of Russian speakers in more detail, it is therefore necessary to develop a model that can take account of all of these aspects including socioeconomics, language, politics, and more cultural understandings such as those encapsulated by memory.

\section{Framework for analysis: Brubaker's 'nationalism reframed' reframed}

From the analysis above it is clear that the interests of researchers have diverged greatly, embracing numerous academic approaches. To what extent then is it possible to employ a single theoretical and analytical framework to bring together this broad range of insights and perspectives? The predominant framework employed in the literature is Rogers Brubaker's triadic nexus (figure 1). Brubaker posited that, in order to understand minority nationalism 
in post-communist Central and Eastern Europe, three categories of analysis were of central importance: 'national minorities, the newly nationalizing states in which they live, and the external "homelands" to which they belong' $(1996,4)$.

Much of the research on Russian speakers in the Baltic states has utilized this framework, with a number of authors adding a fourth node, that of international institutions (Smith 2002; Kelley 2004; Galbreath 2005). As Smith $(2002,3)$ notes, this quadratic approach is more appropriate for the Baltic states as it links 'an ascendant and expansive 'Euro-Atlantic space" to the existing framework. In the Baltic context, this approach has been employed successfully in determining the interplay between international organizations (the EU, OSCE, Council of Europe), external homelands (Russia), nationalizing states (Estonia, Latvia, Lithuania), and national minorities (Russian speakers).

Figure 1: Brubaker's triadic nexus

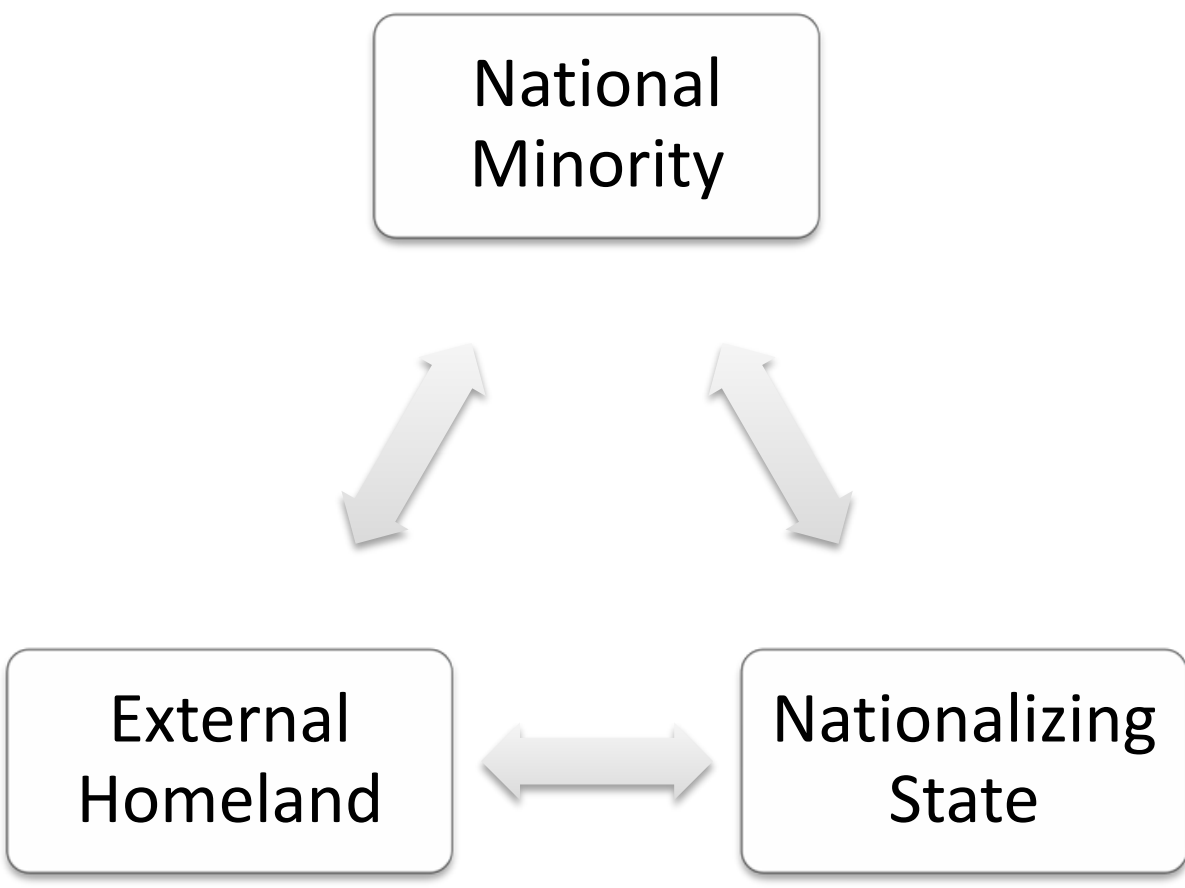

It has been observed, however, that Brubaker's nexus works better as a conceptual model than as a causal construct (Pettai 2006, 133). One reason is Brubaker's insistence that the 
nexus be seen in relative, rather than objective, terms. This proceeds from the author's theoretically complex understandings of nationalism, which he notes are not analytically irreducible (Brubaker 1996, 67).

In order to avoid essentializing the nexus Brubaker depicts the nodes in terms of relative 'fields' which themselves are not static. Additionally, and this has largely been ignored in the subsequent literature, Brubaker notes the importance of stances and representations within the triadic interplay (68-69; see also Pettai 2006, 133). Stances can be understood as discursive practices as well as more concrete policies that emerge from a certain (relative, contested, and non-static) field. Representations, on the other hand, are the selective ways that an external field is perceived. Although Brubaker goes into very little detail, it is surprising that this aspect of the nexus has not been explored more fully.

For Brubaker's nexus to be effectively utilized it is important to combine the study of policies and events with discursive, perceptual elements. By merging these considerations into our understanding of stances and perceptions the nexus becomes more useful in understanding the conflicting processes surrounding the formation and consolidation of Russian-speaking identity. Indeed, it is my argument that this framework can help to explain why a solidified form of Russian-speaking identity has emerged in some respects, while it is also weakly formulated in others.

Significantly, the data presented above give reason to believe that a high number of Russian speakers continue to represent and perceive the Baltic states as nationalizing and discriminatory. This is not to say that the Baltic states are discriminatory. Rather, as Brubaker himself notes, it is more a question of whether states are perceived to be nationalizing than whether they are 'really' nationalizing (Brubaker 1996, 63).

On the other hand, the evidence also suggests that Baltic Russian speakers increasingly perceive themselves as different from Russians in Russia. In previous research Russian speakers have pointed to their perceived 'Europeaness' as a factor that separates them from Russians in Russia (Cheskin, 2013: 294-295). The globalized, trans-European environs of the EU therefore also influence the position of Russian speakers in the Baltic states (Vihalem \& Masso, 2003: 24). It is therefore essential to understand the complex interplay between the four nodes of the quadratic nexus. 
Russian speakers are subject to a number of contradictory forces. At one level Russianspeaking identity can be solidified through self-marginalizing strategies (Golubeva et al. 2007) which discursively portray 'their' group to be discriminated against by the ('nationalizing') Baltic states. At the same time their identity as Baltic Russians, and therefore distinct from Russians in Russia, pushes them back towards identification with the Baltic states. This, in turn, weakens the internal solidity of a group identity which has been based on the notion that they are, in fact, different from Estonians/Latvians/Lithuanians. Additionally, European structures and discourses also potentially influence identity patterns by providing economic and symbolic inducements away from the homeland nationalism of the Russian Federation.

To complicate matters more, certain stances from the nationalizing state and the external homeland are perceived positively, while others negatively. To make sense of this conceptually, and drawing on the analysis above, a useful approach is to divide each field into the three sub-fields of politics, economics, and culture (see figure 2). This division is not designed to be static. Instead each sub-field refers to the representations that Russian speakers may have of certain aspects of the nationalizing state, their external homeland, and international organizations. Although there are a number of possible international organizations that can influence Russian-speaking identity, for the sake of parsimony, and recognizing the preeminent role of the $\mathrm{EU}$, the following section focuses exclusively on the European Union (understood as a symbolic, political, and territorial entity) when referring to the fourth node of 'international organizations'. It is important to note that, as with Brubaker's original fields, the sub-fields are highly contested, negotiable, and subject to change.

The four categories help to conceptualize the extent by which individuals relate to, identify with, or feel estranged from each node. Politically this is manifested in, among other things, support for (or opposition to) the independence of their country of residence, levels of trust and participation in political channels of representation, degrees of support for European integration, and territorial identification with Estonia/Latvia/Lithuania. Similarly the sub-field of economics describes the socio-economic push/pull factors that orient individuals positively or negatively towards each node. The cultural sub-field refers to how cultural stances and representations, such as memory orientation, linguistic practices, and ethnic 
traditions affect individuals' identification with the 'nationalizing state', 'external homeland', or 'international organizations'.

Using this expanded frame of reference we can see some of the contradictory identity pressures that Russian speakers encounter. Table 1 postulates how each sub-field acts either as a positive or negative pole of attraction. It is acknowledged from the outset that this tabulation is not without its ontological and epistemological problems. For one thing there is the danger of essentializing group identity for Russian speakers by suggesting that they will all be similarly affected by each of these nodes. Nevertheless, by concentrating on what Brubaker has elsewhere termed a process-focused approach $(2004,11)$, we are able to move beyond simplistic approaches which reify collective identities - 'groupism' in Brubaker's parlance (1998). A process-focused approach reflects an attempt to understand not what a nation or group is, but rather how particular categories of race, nation or ethnicity work (Brubaker 2009, 29).

Figure 2: The reframed (quadratic) nexus

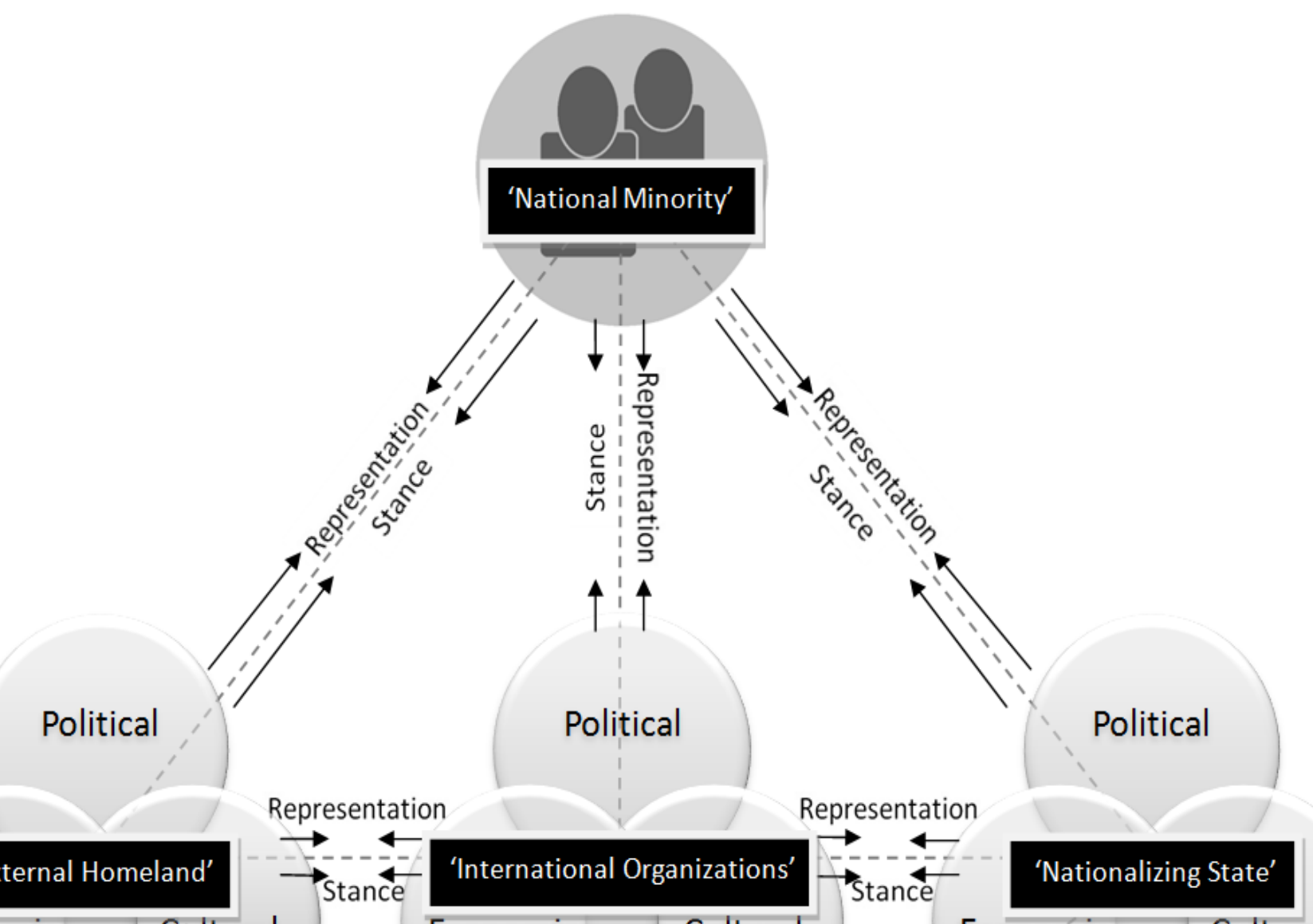


Table 1: External homeland, nationalizing states, and international as positive and negative poles of attraction for Russian speakers

\begin{tabular}{|c|c|c|c|c|c|c|c|c|}
\hline \multicolumn{3}{|c|}{$\begin{array}{c}\text { External homeland } \\
\text { (Russia) }\end{array}$} & \multicolumn{3}{|c|}{$\begin{array}{l}\text { Nationalizing state } \\
\text { (Estonia, Latvia, } \\
\text { Lithuania) }\end{array}$} & \multicolumn{3}{|c|}{$\begin{array}{c}\text { International } \\
\text { Organization (EU) }\end{array}$} \\
\hline Political & Economic & Cultural & Political & Economic & Cultural & Political & Economic & Cultural \\
\hline$-/+$ & - & + & $-1+$ & + & - & + & + & + \\
\hline
\end{tabular}

The table therefore does not indicate the 'real' relationship between the separate fields of the nexus. Instead it considers how the relationships might be perceived by a number of Russian speakers. Other Russian speakers may experience different perceptions, which in turn may create further contestation within the relative fields. Nevertheless the positive and negative indicators in the table are inferred from the analysis presented above. There is therefore some justification in employing these generalized indicators in order to come to a better understanding of the processes which potentially affect Russian-speaking identity in the Baltic states.

As highlighted above, the relative strength of the Baltic states' economic position logically weakens identification with the Russian Federation. Additionally there is little evidence that the majority of Russian speakers in the Baltic states have strong political identification with 
Russia (although specific individuals and groups will differ). The field of cultural perceptions and stances, however, holds much more appeal for Russian speakers (see Vilhalem \& Masso, 2003: 103). Whether it is Russian historical narratives, consumption of Russian media and entertainment, or affinity with the Russian language, these cultural aspects within the homeland nationalism field appear far more attractive than the sub-fields of economics and politics. In this sense the reframed nexus is conceptually useful as it allows Russia to act as a cultural homeland for people who are not ethnically Russian. A 'Russian-speaker', who is ethnically Belarusian, for example, may feel significant attraction to Russia on linguistic and cultural grounds even when Russia is not considered as an ethnic homeland per se.

The value of the reframed nexus is therefore that it allows us to examine the influence of the Russian Federation even for people who do not explicitly consider it to be an 'external homeland'. Admittedly, the term external homeland is itself problematic, especially for many Russian speakers who have had no experience of life in Russia, or who are not even ethnic Russians. Nevertheless, the validity of this concept is maintained by the continued insistence by Russian authorities that they have a duty to protect the rights of 'Russian speakers' (for example President of Russia 2014).

With respect to the Baltic states, there is still good reason to believe that Russian speakers continue to perceive many of the nation and state building stances of these countries rather negatively. Estonian and Latvian integration programmes, for example, are often viewed as one-way processes of assimilation into the 'core culture' of the 'titular nation'. David Smith has termed this process 'dissimilation' whereby the titular culture of the Baltic states is deliberately separated and demarcated from the cultural practices of the non-titulars (2005, 188). This, of course, potentially erodes political identification.

Conversely, increasing numbers of Russian speakers now have Latvian and Estonian citizenship and therefore feel potentially less alienated from the political process. Because Lithuania adopted the 'zero' option of citizenship it is common to treat the country as fundamentally different from Latvia and Estonia. While in the cultural sphere Lithuanian language laws show a great deal of overlap with those of Latvia and Estonia, politically, because of its liberal citizenship laws, Lithuania is more attractive to Russian speakers than the other two Baltic states. This is reflected in survey data that show consistently higher 
levels of attachment by Russian speakers to Lithuania compared to Latvia or Estonia, as well as lower levels of identification with Russia (Muižnieks, Rozenvalds \& Birka 2013, 302-306).

The impact of the European Union is perhaps more difficult to assess as there is a relative scarcity of research that has explored stances and perceptions of Russian speakers in relation to the EU along the political, economic, and cultural axes. Nevertheless, the fact that many Russian speakers point to their Europeanization as a factor that differentiates them from Russians (see above), indicates a certain level of positive cultural attraction towards the EU. Because the Baltic states are EU members, this helps to orient Baltic Russian speakers towards their 'nationalizing state'. Additionally, even when Russian speakers feel politically alienated from the Baltic states, Russia's attractiveness is reduced by perceived economic opportunities in other EU countries (Aptekar 2009). Because Estonian, Latvian, and Lithuanian citizenship is concurrently EU citizenship, we may speculate that politically the EU is an attractive force that adds value to Baltic citizenship. However, more research is needed in this area.

As well as helping to understand some of the trends in group identity formation, the tabulation in table 1 helps to obtain a more comprehensive understanding of integration strategies. Earlier it was noted that Russian speakers in Latvia and Estonia have displayed increasing levels of structural and cultural integration (measured by access to political and social channels and knowledge of the state language respectively). At the same time, levels of social and identificational integration have remained relatively low. Cultural integration is rather narrowly defined in this respect and does not correspond to the much broader subfield of culture which has been employed within the nexus. With these trends in mind, focus on the nexus' sub-fields allows us to see direct links between the complex interplays between nationalizing states, national minorities, national homelands, and international organizations.

It is fair to suggest that the sub-fields of politics and economics, although sometimes contradictory, generally exert a positive pull on Russian speakers towards the Baltic states. There are real (and perceived) political and economic incentives for Russian speakers to acquire Baltic citizenship and to learn the state languages. We may posit that Russia 
generally does not offer the same level of political or economic attractiveness. As a result we can witness relatively high structural and cultural integration.

However, it is important not to overlook entirely the potential for Russia's political attractiveness. In 2013, for example, there were a reported 93,795 Russian citizens in Estonia and 43,586 in Latvia (Muižnieks, Rozenvalds \& Birka 2013, 292). Using crude calculations this amounts to approximately $29.6 \%$ and $6.7 \%$ of the Russian-speaking populations of the two countries respectively. ${ }^{10}$ While the validity of such figures has been questioned (Pettai \& Hallik 2002, 527) they nevertheless indicate, especially for Estonia, that Russian citizenship retains some appeal for at last a proportion of the population.

The relatively higher percentage of Estonia's Russian speakers with Russian citizenship has been traced back to the uncertainty surrounding the country's 'law on aliens', whereby noncitizens were required to register for temporary residency permits (Semjonov 2002: 121-4; Muižnieks, Rozenvalds \& Birka 2013: 292). This highlights the importance of domestic stances in determining political orientations. In Lithuania the political attraction of the 'nationalizing state' is markedly more apparent thanks to the country's less restrictive citizenship laws. This is reflected in levels of identification with Russia and Lithuania among resident Russian speakers (see above).

On the other hand, notwithstanding successes in terms of structural and cultural integration, identificational integration remains relatively low (especially for Latvia and Estonia). This can be attributed to the greater level of attractiveness that the external homeland represents in this area. Additionally, the cultural stances of the Baltic states continue to be perceived rather negatively. Many Russian speakers therefore still view Baltic cultures in terms of 'their' and not 'our' culture (Cheskin 2013, 304-305). This is especially true for Latvia and Estonia, where the titular cultures and languages have not been projected as inclusive, but instead in highly ethnicized terms. This can be seen in the restrictive citizenship laws and the particularly one-sided premises of the countries' respective integration programmes. For the case of Lithuania the cultural attraction of the Lithuanian state for Russian speakers appears to be more positive than for their counterparts in either Latvia or Estonia. To some extent, however, identification with the abstract concept of Europe can mitigate the cultural push 
factor of the nationalizing state by offering Russian speakers a layer of identification that further demarcates them from Russians in Russia.

Overall then this differentiated approach to Brubaker's triadic nexus is very fruitful. Rather than seeing 'nationalizing states' as monolithic entities that either attract or repel 'national minorities', this expanded model shows the contradictory influences of each of the nodes on the nexus. It also allows us to hypothesize conditions that would facilitate full assimilation, integration, marginalization, and separation (table 2).

For full assimilation to occur Russia would need to have very little attraction while the Baltic states would require significant attraction either directly, or indirectly, via the appeal of the EU and 'Europeaness'. For integration The Baltic states would need to exert similarly high levels of attraction but Russia would need to exert some form of cultural appeal. Marginalization would occur when none of the three nodes exerted any meaning attraction. Full separation, for its part, would be likely where the external homeland was significantly more attractive than the nationalizing state of residence. In all of these instances, stances and representations of and towards the EU can be expected to correlate with levels of attraction with the Baltic states. Because, unlike Russia, the Baltic states are EU member states, we can expect positive association with the EU to correlate with positive association with Estonia, Latvia, and Lithuania.

Table 2: Hypothetical conditions for full assimilation, integration, marginalization, and separation of Russian speakers

\section{1: Full assimilation}

External homeland (Russia) Nationalizing state (Estonia, International Organization Latvia, Lithuania)

\begin{tabular}{ll|ll|ll} 
Political Economic Cultural & Political Economic Cultural & Political Economic Cultural
\end{tabular}

\section{2: Full integration}

External homeland (Russia) Nationalizing state (Estonia, Latvia, Lithuania)

International Organization

(EU)

\begin{tabular}{ll|ll|ll} 
Political Economic Cultural & Political Economic Cultural & Political Economic Cultural
\end{tabular}




\section{3: Full marginalization}

External homeland (Russia)
\begin{tabular}{|ccc|ccc|ccc|}
\multicolumn{2}{c}{ Nationalizing state (Estonia, } & \multicolumn{3}{c}{ International Organization } \\
Latvia, Lithuania) & \multicolumn{3}{c|}{ (EU) } \\
Political & Economic & Cultural & Political & Economic & Cultural & Political & Economic & Cultural \\
- & - & - & - & - & - & - & - & - \\
\hline
\end{tabular}

\section{4: Full separation}

\begin{tabular}{ccc|ccc|ccc|}
\multicolumn{3}{c}{ External homeland (Russia) } & \multicolumn{3}{c}{ Nationalizing state (Estonia, } & \multicolumn{3}{c}{ International Organization } \\
LaU) \\
Political & Economic & Cultural & Political & Economic & Cultural & Political & Economic & Cultural \\
+ & + & + & - & - & - & - & - & - \\
\hline
\end{tabular}

Naturally, however, the actual situation facing Russian speakers (generalized in table 1) is more ambiguous and contradictory than in these hypothetical scenarios. Table 1 attempts to reflect the complex realities of the formation of Russian-speaking identity in the Baltic states, as well as the unclear patterns of integration that currently occur. In reality, neither Russia nor the Baltic states are sufficiently attractive or repellent to create conditions conducive to any one of these four integration strategies (although the situation will differ from individual to individual). It also means that there are certain incentives to form a consolidated group identity, while simultaneously opposing pressures against such a development.

\section{Conclusions}

Perhaps one of the most fundamental, and yet complex, questions this paper has addressed relates to the group status of Russian speakers. Do Russian speakers actually constitute a national minority? Obviously this question needs to be addressed at a discursive level where it is understood that all nation groups are ultimately imagined. Nevertheless, the survey of the current literature, combined with the insights from Brubaker's nexus, allow us to see the contradictory processes that both facilitate and impede the formation of a 'Russian-speaking nationality' in the Baltic states. We may conclude that a relatively stable form of Russianspeaking identity has emerged but that it remains fairly fragmented. For a more consolidated identity to develop two main changes are necessary. Firstly Russian speakers would have to perceive their 'nationalizing states' of residence more negatively. Secondly, they would have to perceive their 'external homeland', the Russian Federation, more positively. 
As the current situation stands, the interplay between the stances of the Baltic states and the perceptions of Russian speakers is such that there is generally more positive attraction than negative towards Estonia, Latvia, and Lithuania. Socio-economics plays a large part in this as the perceived economic advantages of being resident in the Baltic states disincentivize certain forms of identification with Russia. This is most keenly felt in Estonia, the most economically successful of the Baltic states. Conversely, cultural identification with Russia remains relatively strong because Russia maintains positive influence through media and the Russian language, and because the stances of the Baltic states continue to be viewed as culturally discriminatory. Politically Estonia's and Latvia's restrictive citizenship laws act as repellent forces against the Baltic states. Nevertheless, this is somewhat mitigated by the rise in Russian speakers who now hold Baltic citizenship, as well as the fact that Russia holds relatively little political attraction of its own. Because of Lithuania's more liberal citizenship policies Lithuania has considerably more political attraction than either Latvia or Estonia. Socio-economic factors, therefore, reduce the capacity for a consolidated identity; political factors slightly reduce this capacity; while cultural factors increase the potential for a consolidated group identity.

It should be noted, however, that further research needs to be conducted in order to build up a more comprehensive picture of how the political, economic, and cultural sub-fields affect different geographical and socio-economic groups of Russian speakers. While the general data suggest that the Baltic states are more economically attractive than Russia, this may be less apparent within disadvantaged socio-economic groups of Russian speakers. For example, vulnerable socio-economic groups are likely to possess lower levels of proficiency in the languages of the Baltic states. In Estonia and Latvia, where knowledge of the state language is a requisite for the acquisition of citizenship, we may posit that such groups will also be more politically estranged than their better-educated counterparts. As Olga Cara's research (2010: 22) has highlighted, although Russian speakers in Latvia generally favour strategies of integration over assimilation, separation, or marginalization, there is still significant support for separation. Cara also notes that 'preference of separation strategy was statistically significantly interrelated with lower level of the Latvian language knowledge' (24). 
Brubaker's nexus has previously been criticized for deemphasizing class as an analytical category (Bogden 2011). The application of the reframed nexus model to different socioeconomic groups would therefore be useful in generating meaningful data that could help to shed further light on the persistence of strategies of separation, and also relative fragmentation among Russian speakers. Certainly, existing data already point to a correlation between low levels of education and disadvantaged economic status on the one hand, and high levels of political disaffection on the other (Agarin 2013: 340).

Additionally, there is a need for this model to be applied more rigorously to the forth node of the nexus - international organizations. While studies have examined the impact of Europeanization and EU-ization on out-migration trends of Russian speakers (Ivievs 2013), more research needs to be conducted examining the cultural, economic, and political effects of such trends on Russian speakers in relation to identification with both their 'nationalizing state' of residence and their 'external homeland'.

While the analysis above is based on data from the existing literature, future research that employs this framework will be able to examine the stances and representations within the nexus in more detail. For example, the stances of the 'nationalizing state' can first be mapped out by examining policy choices and political discourses that relate to the subfields of economics, politics and culture. These can be quantitative economic data and specific policies as well as discursive representations that come from state structures and their associated representatives.

Next, qualitative data from Russian speakers can be used to assess their perceptions of these policies and the affect they have on their identity positions. In other words, fitting with the process-focused approach, the emphasis is not on what policies are, but how they operate and are perceived. At the same time, public portrayals of Russian speaking identity can be categorised as stances in their own right. Again, these can be discursive articulations by political groups and prominent individuals, or they can be concrete actions such as protests or campaigns. These can then be used in a triangulated approach to see how and if the stances of the nationalizing state respond to the publicly articulated positions of Russian speakers. Data for this can be drawn from interviews with cultural and political elites, and also from discourse analysis of public articulations. 
Alongside analysis of the relationship between the 'national minority' and 'nationalizing state', similar analysis of the other relationships in the nexus will facilitate a greater understanding of the complex interplay between all of the nodes on the nexus. Russian policies and initiatives towards their 'compatriots abroad', for example, can be analysed in a similar manner to the domestic policies of the 'nationalizing state'.

A final point to emphasize is that the nexus is far from static. Russia's assertive policies and actions in Crimea in 2014, for example, demonstrate that there is continuous scope for Russia to alter its relationship with Russian speakers. In recent years Russia has been placing increasing emphasis on 'soft power', linking the cultural and ethnic links with its 'diaspora' to explicit foreign policy goals (Ministry of Foreign Affairs of the Russian Federation 2013). If Russia is able to build upon its already significant cultural attractiveness in this manner, then Russia will also have much potential to increase its political attractiveness, at least for certain groups of Russophones in the Baltic states. In Latvia this can already be seen in the public support given to Russia's incorporation of the Crimean Peninsula by the increasingly vocal political party 'Russian Union of Latvia' (2014).

Additionally, the stances of the 'nationalizing states' continue to shape identities and integration patterns within the three countries. For the reasons discussed above, in the 1990s Russian speakers generally refrained from opposing restrictive citizenship and language policies through open mobilization. However, with an increasingly assertive and seemingly confident Russia, the implications of further nationalizing policies may be very different today. Not only has Russia been able to maintain cultural appeal, it now has more economic and political potential. For the case of Crimea, Russia was able to refer to historical and cultural ties with the peninsular, but also pointed to the political illegitimacy of the Kyiv ('fascist') authorities and promised Crimean residents higher pensions and economic prosperity (Kyiv Post 2014). The reframed nexus allows us to bear these international and domestic contexts in mind. As such, Baltic policy-makers will do well to consider carefully the representations that their policy and discursive stances will produce among Russian speakers. When making these domestic policy assessments the economic, political, and cultural appeal of Russia should never be ignored. 


\footnotetext{
${ }^{1}$ In this article Russian speakers (without a hyphen) is used to describe individuals whose first language is Russian. Russian-speakers (with a hyphen) is used to refer to a group, understood as an imagined community. For grammatical clarity the hyphen is maintained when using the term in adjectival form, e.g. 'Russian-speaking identity'.

${ }^{2}$ For an overview of Soviet nationalities policies see Kaiser 1997

${ }^{3}$ Within the federal system of the Soviet Union titular ethnicity (titul'naya natsional'nost') refered to the ethnic groups which gave their name to union republics, autonomous republics, autonomous oblasts, and autonomous okrugs; their so-called 'root nation' (Korennaya natsiya). In the Latvian Soviet Socialist Republic 'Latvians' were the titular nation; in the Chechen-Ingush Autonomous Soviet Socialist Republic - 'Chechens' and 'Ingushians' etc.

${ }^{4}$ Nimmerfeldt et al. define structural integration as 'the acquisition of rights and equal access to the major institutions of society'. Cultural integration is defined as 'the process of cognitive, behavioural and attitudinal change that occurs when individuals from different cultures come into contact.' Social integration they define as 'the degree to which members of different groups are segregated and the degree to which they interact'. Finally, they define identity integration as focusing on 'ethnic and national self-identifications.' (2011: 78-79)

${ }^{5}$ For detailed accounts see Brüggemann \& Kasekamp (2008) and Smith (2008).

${ }^{6}$ The wage gap in Estonia was $16 \%$ and $9 \%$ in Lithuania

${ }^{7}$ For a debate on this issue see Hughes (2005b) and Muižnieks (2005).

${ }^{8}$ Exit can be defined as secession from the dominant regime by a group, or outward migration for individuals, or symbolic exit whereby individuals and groups reside in a given territory but take relatively little interest in political, economic, or social life. Loyalty is generally manifested in assimilation or integration into the host society. Voice represents ethnic mobilization through non-violent engagement with institutions and politics, or through recourse to more militant channels. See Evans 1998, 59.

${ }^{9}$ This is despite the fact that there have been a number of visible exceptions including the education reform protests in 2003/4 and attempts to give Russian the status of a second state language. While significant, these events have passed relatively quickly and have not mobilized Russian speakers to more permanent forms of protest or contention.

${ }^{10}$ These calculations are based on numbers of Russians, Belarusians, and Ukrainians in each country from 2011 census data: Source: Central Statistical Bureau of Latvia and Statistics Estonia.
}

\section{Bibliography}

Aasland, A, (1994) The Russian population in Latvia: An integrated minority?, Communist Studies and Transition Politics, 10(2), pp. 233-60.

Aasland, A. \& Fløtten, T. (2001) Ethnicity and social exclusion in Estonia and Latvia, EuropeAsia Studies, 53(7), pp. 1023-49. 
Agarin, T. (2009) Cooptation as integration? National programme 'Integration of Society in Latvia' on minority participation, in: T. Agarin \& M. Brosig (eds), Minority integration in central eastern Europe: Between ethnic diversity and equality, pp. 199-223 (Amsterdam: Rodopi).

Agarin, T. (2010) A cat's lick: Democratisation and minority communities in the post-Soviet Baltic (Amsterdam: Rodopi).

Agarin, T. (2013) Resident Aliens? Explaining Minority Disaffection with Democratic Politics in the Baltic States, Ethnopolitics, 12(4), pp.331-51.

Aptekar, S. (2009) Contexts of exit in the migration of Russian speakers from the Baltic countries to Ireland, Ethnicities, 9(4), pp.507-526.

Barrington, L. W. (2000) Understanding citizenship policy in the Baltic states, in: A. Aleinikoff \& D. Klusmeyer (eds), From migrants to citizens: Membership in a changing world, pp. 253304 (Washington: Brookings Institutional Press).

Berg, E. \& Ehin, P. (2009) Incompatible Identities? Baltic-Russian Relations and the EU as an Area for Identity Conflict, in: E. Berg \& P. Ehin (eds), Identity and Foreign Policy: BalticRussian Relations and European Integration, pp. 1-14 (Farnham: Ashgate).

Berry, J. (1997) Immigration, acculturation, and adaption, Applied Psychology: An International Review, 46(1), pp. 5-68.

Brubaker, R. (1994) Nationhood and the national question in the Soviet Union and postSoviet Eurasia: An institutionalist account, Theory and Society, 23(1), pp. 47-78.

Brubaker, R. (1996) Nationalism reframed: Nationhood and the national question in the new Europe (Cambridge: Cambridge University Press).

Brubaker, R. (1998) Myths and misconceptions in the study of nationalism, in: J. A. Hall (ed.), The state of the nation: Ernest Gellner and the theory of nationalism, pp. 272-306 (New York: Cambridge University Press). 
Brubaker, R. (2004) Ethnicity without groups (Cambridge, MA: Harvard University Press).

Brubaker, R. (2009) Ethnicity race and nationalism, Annual Review of Sociology, 35, pp. 2142.

Brüggemann, K. and Kasekamp, A. (2008) The Politics of History and the "War of Monuments" in Estonia, Nationalities Papers, 36(3), pp. 425-48.

Cara, O. (2010) The acculturation of Russian-speaking adolescents in Latvia, European Education, 42(1), pp. 8-36.

Cheskin, A. (2010) The Discursive Construction of "Russian-speakers": The Russian-language Media and Demarcated Political Identities in Latvia, in: M. Golubeva \& R. Gould (eds), Shrinking Citizenship: Discursive Practices that Limit Democratic Participation in Latvian Politics, pp.133-56 (Amsterdam: Rodopi).

Cheskin, A. (2012) History, conflicting collective memories, and national identities: how Latvia's Russian-speakers are learning to remember, Nationalities Papers, 40(4), pp. 561-84.

Cheskin, A. (2013) Exploring Russian speaking identity from below: The case of Latvia, Journal of Baltic Studies, 43(4), pp. 283-312.

Cianetti, L. (2014) Legislating on language requirements for employment. The intersection between language and democracy in Estonia and Latvia. Conference paper: University of Jyväskylä, available online: https://www.academia.edu/6710547/Legislating_on_language_requirements_for_employment . The intersection_between_language_and_democracy_in_Estonia_and_Latvia

Dobson, J. \& Jones, J. (1998) Ethnic discrimination: public policy and the Latvian labour market, International Journal of Manpower 19(1/2), pp. 31-47.

Ernstsone, V. and Mežs, I. (2008) Language proficiency of the Latvian population, in: R. Apinis et al., Break-out of Latvian: A sociolinguistic study, pp. 187-204 (Riga: Zinātne). 
Estonian Ministry of Culture. (2011) Monitoring of Integration in the Estonian Society in 2011, available online at: http://www.kul.ee/webeditor/files/integratsioon/Monitooring 2011 EN.pdf

Evans, G. (1998) Ethnic schism and the consolidation of post-communist democracies, Communist and Post-Communist Studies, 31(1), pp. 57-74.

Fein, L. C. (2005) Symbolic boundaries and national borders: the construction of an Estonian Russian identity, Nationalities Papers, 33(3), pp. 333-44.

Galbreath, D. J. (2005) Nation-building and minority politics in post-socialist states interests, influence and identities in Estonia and Latvia (Stuttgart: Ibidem-Verl).

Golubeva, M., Rožukalne, A. \& Kažoka, I. (2007) Izaicinājums pilsoniskajai līdzdalībai: Analîtiskais ziṇojums par Saeimas un mediju monitoring (Riga: Sabiedriskās politikas centrs PROVIDUS).

Gruzina, I. (2011) Relationship between history and a sense of belonging - Russian speaking minority integration in Latvia, CEU Political Science Journal, 6(3), pp. 397-432.

Haas, A. (1996) Non-violence in ethnic relations in Estonia, Journal of Baltic Studies, 27(1), pp. 47-76.

Hackmann, J. \& Lehti, M. (2008) Introduction: Contested and Shared Places of Memory. History and Politics in North Eastern Europe, Journal of Baltic Studies, 39 (4), pp. 377-9.

Hazans, M. (2005) Unemployment and the earnings structure in Latvia, World Bank Policy Research Working Paper, no. 3504 (Washington: World Bank).

Heckmann, F. \& Schnapper, D. (eds) (2003) The integration of immigrants in European societies: National differences and trends of convergence (Stuttgart: Lucius and Lucius).

Hogan-Brun, G. (2006) At the interface of language ideology and practice: The public discourse surrounding the 2004 education reform in Latvia, Language policy, 5(2), pp. 31333. 
Hughes, J. (2005a) 'Exit' in deeply divided societies: regimes of discrimination in Estonia and Latvia and the potential for Russophone migration, Journal of Common Market Studies, 43(4), pp. 739-62.

Hughes, J. (2005b) Russophone minorities in Estonia and Latvia, Development and Transition, 2, pp. 22-5.

Ivlevs, A. (2013) Minorities on the move? Assessing post-enlargement emigration intentions of Latvia's Russian speaking minority, The Annals of Regional Science, 51(1), pp.33-52.

Kaiser, R. J. (1997) 'Nationalism and identity', in: M. J. Bradshaw (ed.) Geography and transition in the post-Soviet republics, pp.9-30 (Chichester: John Wiley and Sons).

Kasatkina, N. (2006) Adaptatsiia russkikh v kontekste etnicheskoi struktury sovremennogo obshchestva Litvy [The adaptation of ethnic Russians in the context of the ethnic structure of contemporary Lithuanian society], Studia. Slavica. Finlandensia, 23, pp. 39-68.

Kelley, J. G. (2004) Ethnic Politics in Europe: The Power of Norms and Incentives (Princeton: Princeton University Press).

Kemppainen, R. F., Scott E. W., Carol J. \& Hite, J. M. (2004) "One should not forget one's mother tongue": Russian-speaking parents' choice of language of instruction in Estonia, Bilingual Research Journal, 28(2), pp. 207-29.

Khanov, D. (2002) Роль русской прессы в создании русской идентичности в современной Латвии - утраченная идентичность [The role of the Russian press in the formation of Russian identity in contemporary Latvia - a lost identity] (Riga: Politika.Iv).

Kirch, A. (1992) Russians as a minority in contemporary Baltic States, Security Dialogue, 23(2), pp. 205-12.

Kirch, A., Kirch, M. and Tuisk, T. (1993) Russians in the Baltic states: to be or not to be?, Journal of Baltic Studies, 24(2), pp. 173-88. 
Korts, K. (2010) Inter-ethnic attitudes and contacts between ethnic groups in Estonia, in: M. Lauristin, and P. Vihalemm (eds), Estonia's transition to the EU: Twenty years on, pp. 116-32 (London: Routledge).

Kronenfeld, D. A. (2005) The effects of interethnic contact on ethnic identity: Evidence from Latvia, Post-Soviet Affairs, 21(3), pp. 247-77.

Kruusvall, J. Vetik, R. \& Berry, J. W. (2009) The strategies of inter-ethnic adaption of Estonian Russians, Studies of Transition States and Societies, 1(1), pp. 3-24.

Kyiv Post (2014) Putin orders increase of Crimean pensions to Russian levels. March 19, 2014. Available online: http://www.kyivpost.com/content/ukraine/putin-orders-increase-ofcrimean-pensions-to-russian-levels-339974.html

Laitin, D. D. (1995) Identity in formation: the Russian-speaking nationality in the post-Soviet diaspora, European Journal of Sociology, 36(2), pp. 281-316.

Laitin, D. D. (1998) Identity in formation: the Russian-speaking populations in the Near Abroad (London: Cornell University Press).

Latvian Ministry of Culture (2011) Nacionālās identitātes, pilsoniskās sabiedrības un integrācijas poiltikas pamatnostādnes (2012-2018) [Guidelines for national identity, civil society and integration policy (2012-2018)] (Riga: Latvian Ministry of Culture).

Leping, K. \& Toomet, O. (2008) Emerging wage gap: Estonia during political and economic transition, Journal of Comparative Economics, 36(4), pp. 599-619.

Lerhis, A. (ed.) (2007) Ārvalstu ietekme uz sabiedrības integrācijas procesu Latvijā [Foreign influence on the process of social integration in Latvia] (Riga: Austrumeiropas poiltisko pētījumu centrs).

Linz, J. J. and Stepan, A. (1996) Problems of democratic transition and consolidation: Southern Europe, South America, and post-Communist Europe (London: Johns Hopkins University Press). 
Mälksoo, M. (2009) Liminality and Contested Europeanness: Conflicting Memory Politics in the Baltic Space, in: E. Berg \& P. Ehin (eds), Identity and Foreign Policy: Baltic-Russian Relations and European Integration, pp. 65-84 (Farnham: Ashgate).

Malloy, T. H. (2009) Social cohesion Estonian style: Minority integration through constitutionalized hegemony and fictive pluralism, in: T. Agarin \& M. Brosig (eds), Minority integration in central eastern Europe: Between ethnic diversity and equality, pp. 225-256 (Amsterdam: Rodopi).

Melvin, N. (1995) Russians beyond Russia: The politics of national identity (London: The Royal Institute of International Affairs).

Ministry of Foreign Affairs of the Russian Federation (2014) Concept of the foreign policy of the Russian Federation. Available online:

http://www.mid.ru/brp 4.nsf/0/76389FEC168189ED44257B2E0039B16D

Muižnieks, N. (2005) Response, Development and Transition, 2, pp.26-7.

Muižnieks, N. (ed.) (2010) How integrated is Latvian society? An audit of achievements, failures and challenges (Riga: University of Latvia Press).

Muižnieks, N., Rozenvalds, J. \& Birka, I. (2013) Ethnicity and social cohesion in the postSoviet Baltic states, Patterns of Prejudice, 47(3), pp. 288-308.

Nimmerfeldt, G., Schulze, J. \& Taru, M. (2011) The relationship between integration dimensions among second generation Russians in Estonia, Studies of Transition States and Societies, 3(1), pp. 76-91.

Onken, E. (2007) The Baltic States and Moscow's 9 May Commemoration: Analysing Memory Politics in Europe, Europe-Asia Studies, 59(1), pp. 23-46.

Onken, E. (2010) Memory and Democratic Pluralism in the Baltic States - Rethinking the Relationship, Journal of Baltic Studies, 41(3), pp. 277-94. 
Pettai, V. A. (2003) Prospects of multiethnic democracy in Europe: Debating minority integration in Estonia, in: J. Ferrer and M. Iglesias (eds), Law, politic and morality: European perspectives I, pp. 53-82 (Berlin: Dunker and Humbolt).

Pettai, V. A. (2006) Explaining ethnic politics in the Baltic states: Reviewing the triadic nexus model, Journal of Baltic Studies, 37(1), pp. 124-36.

Pettai, V. \& Hallik, K. (2002) Understanding processes of ethnic control: Segmentation, dependency and co-optation in post-communist Estonia, Nations and Nationalism 8(4), pp. 505-29.

Pisarenko, O. (2006) The acculturation modes of Russian speaking adolescents in Latvia: Perceived discrimination and knowledge of the Latvian language, Europe-Asia Studies, 58(5), pp. 751-73.

Ponarin, E. (2000) The prospects of assimilation of the Russophone populations in Estonia and Ukraine: A reaction to David Laitin's research, Europe-Asia Studies, 52(8), pp. 1535-41.

Poppe, E. \& Hagendoorn, L. (2001) Types of identification among Russians in the 'Near Abroad, Europe-Asia Studies, 53(1), pp. 57-71.

President of Russia (2014) Telephone conversation with President of the United States Barack Obama. News release from official Presidential website. Available online: http://eng.kremlin.ru/news/7020

Raun, T. U. (2009) Estonia after 1991: Identity and integration, East European Politics and Society, 23(4), pp. 526-33.

Russian Union of Latvia (2014) Пикет в подержку Крыма [Picket in support of Crimea]. News item from party's official website. Available online: http://zapchel.Iv/?lang=ru\&mode=archive\&submode=year2014\&page id=11662 
Semjonov, A. (2002) Estonia: Nation-building and integration - political and legal aspects, in P. Kolstø (ed.), National integration and violent conflict in post-Soviet societies: The cases of Estonia and Moldova, pp. 105-58 (Oxford: Rowman and Littlefield).

Smith, D. J. (2002) Framing the national question in Central and Eastern Europe: A quadratic nexus?, Ethnopolitics, 2(1), pp. 3-16.

Smith, D. J. (2005) Managing multiculturalism: The regulation of ethnopolitical disputes in post-Soviet Estonia and Latvia, in: M. Lehti (ed.), The Baltic as a multicultural world: Sea, region and peoples, pp. 183-214 (Berlin: MWV).

Smith, D. J. (2008) 'Woe from stone': commemoration, identity politics and Estonia's 'War of Monuments, Journal of Baltic Studies, 39(4), pp. 419-30.

Smith, G. (1996) The ethnic democracy thesis and the citizenship question in Estonia and Latvia, Nationalities Papers, 24(2), pp. 199-216.

Smith, G. et al. (1998) Nation-building in the Post-Soviet Borderlands: The Politics of National Identities (Cambridge: Cambridge University Press).

Solska, Magdalena (2011) Citizenship, collective identity and the international impact on integration policy in Estonia, Latvia and Lithuania, Europe-Asia Studies, 63(6), pp. 1089-108.

Šūpule, I. (2007) Etniskās attiecības un akulturācijas procesi Latvijā: ledzīvotāju attieksmes pret dažādām akulturācijas stratēǵijām [Ethnic relations and the acculturation process in Latvia: Resident attitudes towards various acculturation strategies], Latvijas Universaitātes Raksti, 714, pp. 31-43.

Tabuns, A. (2010) Identity, ethnic relations, language and culture, in: N. Muižnieks (ed.) How integrated is Latvian society? An audit of achievements, failures and challenges, p.253-278 (Riga: University of Latvia Press).

Toomet, O. (2011) Learn English, Not the Local Language! Ethnic Russians in the Baltic States, American Economic Review, 101(3), pp. 526-31. 
Vihalemm, T. \& Kalmus, V. (2009) Cultural Differentiation of the Russian Minority, Journal of Baltic Studies, 40(1), pp. 95-119.

Vihalemm, T. \& Jakobson, V. (2011) Representations of the past in the Estonian Russianlanguage press: “Own” or “diaspora” memory?, Nationalities Papers, 39(5), pp. 705-31.

Vihalemm, T. \& Masso, A. (2003) Identity dynamics of Russian-speakers of Estonia in the transition period, Journal of Baltic Studies, 34(1), pp. 92-116.

Wertsch, J. V. (2008) Collective Memory and Narrative Templates, Social Research, 75(1), pp. 133-56.

Woolfson, C. (2009) Labour migration, neoliberalism and ethno-politics in the new Europe: the Latvian case, Antipode, 41(5), pp. 952-82.

Zabrodskaja, A. (2009) Language testing in the context of citizenship and asylum: The case of Estonia, Language Assessment Quarterly, 6(1), pp. 61-70.

Zelče, V. (2009) History-responsibility-memory: Latvia's case, in: J. Rozenvalds and I. Ijabs (eds), Latvia . Human development report, 2008/2009: Accountability and responsibility, pp. 44-57 (Riga: University of Latvia).

Zepa, B. (2006) The Changing Discourse of Minority Identities (Riga: Baltic Institute for Social Sciences).

Zepa, Brigita, et al. (2006) Integration practice and perspectives (Riga: Baltic Institute of Social Sciences). 